\title{
Born Deaf Students' English Learning and the Usage of the Multimedia Technology of Higher Special Education ${ }^{*}$
}

\author{
Zhao Chun-hui \\ Changchun University, Changchun, China
}

Liu Fu

Jilin Jianzhu University, Changchun, China

\begin{abstract}
At first, this paper talks about the situation of higher special education in China. Second, it discusses the necessity of English courses for the born deaf in China. At last, it presents the advantages of multimedia network teaching. The application of network technology in special education explores the visions and ways of education for the disabled, and also brings new opportunities for their eduation. So, we must take advantage of this good opportunity, try hard to create the teaching optimization environment, build information education mode, explore the modern education technology, design the teaching optimization process seriously, explore actively, and sum up experience constantly, and promote the modern education technology system in teaching.
\end{abstract}

Keywords: special education, multimedia network teaching, born deaf, English courses

\section{Introduction}

At present, the environment of the whole society on the work of education technology is very good, even we can say that this is the best opportunity in history. Since the information technology (IT) has been used in China's special education in the 1990s, it has gone deeply into deaf students' education and all aspects of life. Deaf students can learn knowledge, know the world, and enrich life through computers. This advanced teaching model greatly changed deaf students' traditional teaching methods and teaching means, and created a new teaching environment for school teaching. In the development of modern special education, it has become a new milestone (Jin \& Lv, 2002, p. 103).

Application of network technology in special education explores the visions and ways of education for the disabled, and also brings new opportunities for their education. So, we must take advantage of this good opportunity, try hard to create the teaching optimization environment, build information education mode, explore the modern education technology, design the teaching optimization process seriously, explore actively, and sum up experience constantly, and promote the modern education technology system in teaching (Zhang, 1995, p. 22).

\section{The Current Situation of Higher Education in China}

According to national handicapped person sampling survey in 1987 , among the 50,000,000 disabled

\footnotetext{
* This paper is a part of the result of the authors' research programs: "Research on Multimedia Application in English Teaching of Higher Special Education" (2014, No. 276), Jilin Education Department Fund Project; and "Research on College English Teaching Strategy of Higher Special Education" (2014, XZYB14-24), Changchun University.

Zhao Chun-hui, M.A., associate professor, Public Foreign Language Teaching and Research Department, Changchun University. Liu Fu, M.A., lecturer, The Hongqi Campus, Jilin Jianzhu University.
} 
people, 154,900 people own a bachelor's degree, accounts for $0.3 \%$ of the total number of the disabled. This shows that higher education for the disabled is still a relatively weak link in special education career. With the improvement of the special education laws and regulations, higher and secondary education for the disabled also received recognition and development. At the same time, education as a national legal school education system also was opened increasingly to more citizens. Since 1985, 1,000 disabled candidates have entered the ordinary university to study. Till 1992, the number of disabled students in ordinary universities has reached more than 700. China also approved that these separate special higher education institutions can recruit students and test them by themselves. Separate test of the born deaf's higher education policy has opened up a new channel for the implementation of deaf students' college dream. The born deaf's higher education entrance examination is the recruitment exam. Independent setting of institutions of higher learning for acceptance of the disabled admit the best examiners according to the examiners' scores. It also has the established recruitment plan and the national standard. So, the college entrance examination will have higher reliability, validity, necessary differentiation, and appropriate difficulties (Piao, 2004, p. 4).

In 1987, Changchun University established a special education college, set up four majors, and recruited three kinds of disabled students. Medical Department of Shandong Binzhou Medical College, Tianjin University of Science and Engineering, Henan College of Traditional Chinese Medicine, and Nanjing College of Traditional Chinese Medicine specifically recruit disabled students. Besides through informal forms of higher education, for example, higher education examination program for the self-taught, correspondence college, night university, and TV university, absorb a large number of disabled people to accept higher education to make up for the deficiency of the ordinary university. Till now, there are about 6,000 disabled students who have attended higher education examination program for the self-taught. At present, higher education for the disabled has covered three kinds of students - blind, deaf, and mutilation, and some severe disabled students have attended self-taught examinations, spaning all levels of higher education for disabled person, from junior college, regular college course to master's degree or doctorate. Involved professions include medicine, fine arts, Chinese, economy, law, foreign languages, math, philosophy, education, and electromechanics. These cases show that China's higher education for the disabled has walked out of a way of characteristic development.

\section{The Necessity of English Courses for the Born Deaf}

World conference on special education passed the Declaration of Salamanca in Spain in 1994, which pointed out that schools should meet the needs of different students. The ultimate goal of education is to develop students, and to make them learn to survive, including the disabled students. So, under the integration education, common colleges and universities should reform themselves to maximize the possibility to meet the needs of different students. The necessity of English courses for the born deaf include:

1. The requirements of the born deaf to improve their own quality. The born deaf students should grasp the basic English knowledge, so they can adjust to the society better and find more ideal jobs;

2. The requirements of adjusting to the society. Now, we are living in an information and knowledge-based society. Although Chinese born deaf can use high-tech products of Chinese character system, a lot of high-tech products cannot be improved without foreign knowledge and there are many English words on the Internet, so grasping some common English words and phrases is modern deaf students' essential life elements. At the same time, with social development, international communication increases frequently. The opportunity of deaf people contacting with foreigners also increases gradually. In order to strengthen the 
understanding to the world, it is necessary for the deaf people to learn English or other foreign languages in school (Xu, 2011, p. 44);

3. The requirements of the born deaf people to find jobs in the future. The aim of born deaf students studying in school is to improve their own qualities, to acquire some professional skills, and to create conditions for them entering the society in the future. Born deaf students are healthy, their memory and observation are extremely strong. If they own the same degree and knowledge level as normal people, they can participate in equal competition for social work (Ma, 2005, p. 44).

\section{Multimedia Network Teaching in Deaf Students' Higher Education Delivery}

With the implementation of compulsory education and the rising enrollment rate of special children in China, special education gradually becomes popular, so how to improve the quality of special education has gradually evolved into the center of the problem. In the process of improving the quality of special education, computer has great potential, and it also should play more positive roles to become an important means to improve the quality of special education delivery. As Kirt and Gallagher (as cited in Li, 2013) said:

In accepting and using education technology, special education is in a leading position. Among various kinds of technical equipment, the latest and the most significant one is micro-computer. Because micro-computer shows the unique advantage to the special children, so it is especially important in special education. (p. 336)

Higher network education in China started in 1998. According to 2004s special education school's computer hardware and the investigation of campus network construction situation, although the sizes range, more than $90 \%$ of the special education schools have its own computer rooms. Visibly, along with the rapid development of social economy and IT, special education schools have fully realized that using computer technology in deaf students' education has special importance. But a quarter of these 12 schools cannot surf the Internet. There are all kinds of reasons, but it shows that deaf students using the Internet for learning and communicating has not drawn the attention of all the higher education institutions.

\section{Conclusion}

Due to physical disabilities, disabled students are influenced to know and contact the world. In terms of studying, they are poorer than ordinary college students and they are very dependent. Because of language and hearing obstacles, born deaf students mainly depend on their visual sense. They have poor abstract logical thinking. Living in a relatively closed world for a long time, in the development of personality, the disabled students produce more undesirable personality of solitary, suspicion, stubborn, and extreme. The physical and psychological personality of the disabled students get less amount of information and the information is not systematic.

Because deaf students' learning of English has its particularity - they use eyes and sign language to learn and read-it is impossible for them to do listening and speaking training. Recently, the multimedia technology grows rapidly and gradually entering the classroom. Multimedia technology assists language learning, and vividly illustrates the teaching content by means of pattern of manifestation. So, it broadens students' vision, expands the information capacity of classroom teaching effectively, and improves teaching efficiency. The usage of multimedia-assisted language teaching is advantageous to students' intelligence development, ability training, and quality improvement. This teaching pattern can greatly enhance people's understanding and feeling of the abstract things and process by the special expression across time and space, led the classroom teaching to a new realm. 


\section{References}

Jin, Y., \& Lv, X. (2002). On multidimensional development higher special education in new situation. Changchun: Changchun University Publishing House.

Li, X. (2013). The construction of English curriculum system of deaf school in the context of internalization. Jiamusi Journal of Jiamusi Institute of Education, 10, 51-54.

Luo, T. (2002). Study on feminism literature and European American English. Beijing: Oriental Press.

Ma, Y. (2005). On higher special education school deaf English courses. Career, 1, 38-42.

Piao, Y. X. (2004). The establishment and development of high grade special education for disabled person. Beijing: Huaxia Publishing House.

$\mathrm{Xu}$, J. Z. (2011). Using multimedia teaching, improve the quality of physical education teaching. Information Technology Education of China, 8, 44.

Zhang, G. Y. (1995). Computer-assisted foreign language teaching and researching. Shanghai: Foreign Language Education Press.

Zhu, W. Z. (2004). Foreign literary history. Tianjin: Nankai University Press. 